\title{
Thermo-mechanical processing and phase analysis of titanium alloys with copper additions
}

\author{
KD Ukabhai ${ }^{a, b, *}$, KT Nape ${ }^{a, b}$, L Spotose ${ }^{a, b}$, M Mavundlaa, ${ }^{a, b}$, IA Mwamba ${ }^{b, c}$, MO Bodunrin $^{a, b, d}$, LH Chown ${ }^{a, b}$, LA Cornish ${ }^{a, b}$ \\ a School of Chemical and Metallurgical Engineering, University of the Witwatersrand, Private Bag 3, WITS, 2050, South Africa \\ ${ }^{b}$ DSI-NRF Centre of Excellence in Strong Materials, hosted by the University of the Witwatersrand, Johannesburg, Private Bag 3, WITS, 2050, \\ South Africa \\ 'Advanced Materials Division, Mintek, Private Bag X3015, Randburg, 2125, South Africa \\ ${ }^{d}$ African Academy of Sciences, P.O. Box 24916-00502, Nairobi, Kenya \\ Email:*669011@students.wits.ac.za,573762@students.wits.ac.za,2187508@students.wits.ac.za,1597090@students.wits.ac.za, alainm@ \\ mintek.co.za, michael.bodunrin@wits.ac.za, lesleyhchown@gmail.com, Lesley.cornish@wits.ac.za
}

\begin{abstract}
In dentistry and orthopaedics, to replace and mend broken bones, any replacement material needs to have: low density, high strength, good biocompatibility and must be able to integrate closely with the bone. Titanium-based alloys have these properties, although currently used alloys contain toxic elements, and commercially pure Ti does not have sufficient strength. Within ten years, $7 \%$ of dental implants have complete failure, mainly from bacterial infection. Therefore $\alpha+\beta$ type Ti-alloys were developed by adding $b$ stabilisers, with similar phase proportions to Ti-6Al-4V without the toxic elements, with $\mathrm{Cu}$ additions for antibacterial properties and $\mathrm{Ru}$ for corrosion resistance. Deformation behaviour of Ti-6Al-4V and Ti-Ta-Nb-Zr alloys were also studied using a Gleeble thermomechanical simulator. The compositions of the new alloys were derived using Thermo-Calc. Ti-8Nb-4Zr alloys had bimodal microstructures and the addition of $\mathrm{Cu}$ formed the $\mathrm{Ti}_{2} \mathrm{Cu}$ phase. The Ti-6 Ta- $1.5 \mathrm{Zr}$ and Ti-6 Ta-1.5Zr-0.2Ru alloys with no $\mathrm{Cu}$ had coarse $\alpha$ lamellae, whereas the alloys with $\mathrm{Cu}$ had parallel $\alpha$ plates. The Gleeble results showed that higher flow stresses were obtained at higher strain rates and lower temperatures, agreeing with literature. At $850^{\circ} \mathrm{C}$, the Ti-6Al-4V alloy had higher flow stresses than Ti-10.1 Ta-1.7Nb-1.6Zr. The Ti-6Al-4V and Ti-10.1 Ta-1.7Nb-1.6Zr alloys had steady-state flow stresses at $950{ }^{\circ} \mathrm{C}$, and continuous flow softening at $850{ }^{\circ} \mathrm{C}$ for both strain rates.
\end{abstract}

\section{Introduction}

Biomedical materials are used daily to improve the lives of many people. These materials are used in various parts of the human body as intravascular stents, heart valves, replacement implants in knees, hips, elbows, shoulders, ears and dentistry (Geetha et al., 2009; Zhang et al., 2011). With ageing populations, there is increased demand for biomedical materials with long life spans that do not require revision surgery once implanted. One of the main causes for failure of dental implants is peri-implantitis, which is a site-specific infectious disease that causes inflammation in soft tissues, and bone loss around an osseointegrated implant (Persson and Renvert, 2014).

Biomedical materials have been studied since the 1980s, and typically include $316 \mathrm{~L}$ stainless steel, Co-Cr based alloys and $\mathrm{Ti}$ alloys (Navarro et al., 2008; Khan et al., 2006). However, there are issues with these materials. For example, stainless steel is prone to sudden failure (Bundy et al., 1983), whereas Co-Cr based alloys and $\mathrm{Ti}$ alloys such as $\mathrm{Ti}-6 \mathrm{Al}-4 \mathrm{~V}$ can release unfavourable toxic metals into the body (Okazaki and Gotoh, 2005).

Biomedical materials need to have high corrosion and wear resistance, be highly biocompatible and have a comparable modulus to the bone. For these reasons Ti-alloys have been used in recent years, due to their high specific strength, excellent corrosion resistance, low elastic modulus, and superior biocompatibility (Calin et al., 2007; Zhang et al., 2007). Titanium alloys have been designed not only for medical use, but also for jewellery, aerospace, military, automobiles and mobile phones (Calin et al., 2007; Zhang et al., 2007). Compared to 316L stainless steel and Co-Cr, Ti-alloys have significantly lower densities, and their elastic modulus is much closer to those of the bone (Mitragotri and Lahann, 2009).

There are five types of Ti-alloys: $\alpha$-type and near $\alpha$ type, $\alpha+\beta$ type, $\beta$-type and shape memory (Zhang et al., 2011). The $\alpha$-type alloys have not been used due to low mechanical and fatigue strength in load bearing applications (Mitragotri and Lahann, 2009). The $\alpha+\beta$ type alloys have good corrosion resistance and excellent capability of osseointegration (integration of materials into bone) (Stenlund et al., 2015; Sidambe, 2014), although the elastic moduli are higher than of the bone (Lindahl and Lindgren, 1967; Burnstein et al., 1976). The $\beta$-type alloys are currently being developed the most, due to their low elastic moduli, and high strength for load bearing uses (Zhang et al., 2011). However, $\beta$-type alloys are expensive since their alloying elements are expensive, and not many thorough investigations have been done to determine their reliability in the human body during long term service (Zhang et al., 2011). However, currently used Ti-6Al-4V contains toxic vanadium (V) (Choubey et al., 2004; Tamilselvi et al., 2006). Ti-6Al-7Nb and Ti$5 \mathrm{Al}-2.5 \mathrm{Fe}$ were developed to replace Ti-6Al-4V (Choubey et al., 2004; Tamilselvi et al., 2006), but these alloys contain aluminium (Al), which can lead to diseases such as Alzheimer's (Li et al., 2014). 
Thus, it would be advantageous to develop a Ti alloy with neither $\mathrm{V}$ nor $\mathrm{Al}$, so $\alpha+\beta$ type alloys for dental screws were derived by adding $\alpha$ and $\beta$ stabilisers to Ti, to mimic the beneficial $\alpha+\beta$ phase proportions of Ti-6Al-4V, which was used as a reference material. Zirconium, tantalum, niobium and molybdenum were proposed as potential non-toxic alloying elements, since they are $\beta$ stabilizers (Eisenbarth et al., 2004). They are considered as biocompatible (Kuroda et al., 1998; Eisenbarth et al., 2004), because they minimize adverse tissue reactions originating from the release of metal ions from the implant (Meng et al., 2014). Other additions to the alloys considered were copper $(\mathrm{Cu})$ and ruthenium $(\mathrm{Ru})$. Copper is one of the most promising alloying elements for clinical applications because of its low toxicity and high cytocompatibility (Jin et al., 2015), and $\mathrm{Ru}$ is a noble element which improves corrosion resistance in Ti-alloys, even in extremely small amounts (Schutz, 1996). The alloy must mimic the phase proportions of Ti$6 \mathrm{Al}-4 \mathrm{~V}$, which is done by varying the alloy component proportions to achieve the targeted phase proportions, as Stenlund et al. (2015) did. The alloys should be fairly low cost, easy to manufacture, have good mechanical properties and be biocompatible with the human body. The moduli of the alloys must be comparable to that of the bone (10-40 GPa) (Nang et al., 2005).

The Ti-10.1Ta-1.7Nb-1.6Zr (TTNZ) alloy was developed as an implant material (Stenlund et al., 2015) to improve mechanical strength and osseointegration, and mimic the phases of Ti-6Al-4V. However, no studies were done on thermo-mechanical processing of the alloy, which could provide information for shaping it. Hot compression testing is a thermo-mechanical test, which can be used to study flow stress, stress-relaxation, hot workability, and flow softening behaviour due to recrystallisation and recovery (Jha and Kumar, 2010). Therefore, hot compression testing was done on Ti-10.1 Ta-1.7Nb-1.6Zr and Ti-6Al-4V alloys using the Gleeble $3500^{\circledR}$ to compare their behaviour. Thermo-mechanical studies done on Ti-6Al-4V showed that low strain rate at higher temperature improved the ductility, and higher flow stresses were observed at higher strain rate and lower deformation temperatures (Vanderhasten, 2008; Shaikh et al., 2015; Dos Santos, 2017; Bodunrin, 2018).

\section{Experimental procedure}

\section{$2.1 \alpha+\beta$ alloys}

The compositions of different alloys were determined using Thermo-Calc, with the TTTI 3 database, and composition which gave similar $\alpha$ (hcp) and $\beta$ (bcc) proportions to Ti-6Al-4V and Ti10.1 Ta-1.7Nb-1.6Zr were selected (Table 1). The compositions were then made up as arc melted buttons, by mixing $99.9 \%$ pure elemental powders. The weighed out mixed powders were cold compacted with a hydraulic press and then melted in a button arc furnace, which was purged with argon gas and used a titanium oxygen-getter, as commonly used. The buttons were then cut and prepared metallographically for analysis.
Table 1: Compositions of alloys determined from Thermo-Calc

\begin{tabular}{lll}
\hline Alloy & Composition $(\mathbf{w t} \%)$ & \\
\hline 1 & Ti-8Nb-4Zr & Ti-8Nb-4Zr-5Cu \\
2 & Ti-6Ta-1.5Zr & Ti-6Ta-1.5Zr-5Cu \\
3 & Ti-6Ta-1.5Zr-0.2Ru & Ti-6Ta-1.5Zr-0.2Ru-5Cu \\
4 & Ti-2Ta-8Mo-8Sn & Ti-2Ta-8Mo-8Sn-5Cu \\
\hline
\end{tabular}

The buttons were cut using a Struers Secotm-10 cutting machine, with a diamond MOD13 blade. The pieces were mounted in polyfast using an ATM-Opal 410 hot mounting press, then ground (P400, P800, P1200 and P2400 papers) and polished (MD-Chem cloth) by hand on a Struers Tegramin- $20^{\circledR}$ machine.

The samples were then etched using Kroll's reagent and examined on a cross-polarized and Leica DM $6000^{\circledR}$-Light Optical Microscope (LOM) and a Sigma Zeiss scanning electron microscope (SEM) in backscattered (BSE) and secondary electron (SE) modes, and representative images are shown here. The phases of the samples were analysed by energy dispersive X-ray spectroscopy (EDS) in the SEM.

\subsection{Thermo-mechanical testing}

The as-received Ti-6Al-4V and Ti-10.1Ta-1.7Nb-1.6Zr (TTNZ) (Stenlund et al., 2015) alloys were subjected to isothermal compression testing using a Gleeble $3500^{\circledR}$ Thermomechanical Simulation Facility. Cylindrical samples of $8 \mathrm{~mm}$ diameter $\mathrm{x} 12$ $\mathrm{mm}$ height were machined using electric discharge machining. Prior to compression testing, a chromel-alumel thermocouple was welded to the centre of the test samples using a spot welder, to measure the temperature. The samples were then placed on the Hydrawedge autoloader. Graphite foil and nickel paste were placed between the Iso-T tungsten carbide anvils and the sample to reduce the effect of friction during deformation.

The samples were heated at $5{ }^{\circ} \mathrm{C} / \mathrm{s}$ to the deformation temperature, and held for $360 \mathrm{~s}$ for homogenisation, then deformed at the parameters specified in Table 2, followed by compressed air cooling. The test parameters were used in the Quicksim software using the (.hds) program, which was then converted to Gleeble Script Language (.gsl) before running each experiment.

Table 2: Hot compression testing parameters

\begin{tabular}{ccccc}
\hline \multicolumn{2}{c}{ Deformation parameters } & \multicolumn{2}{c}{ Temperature $\left({ }^{\circ} \mathbf{C}\right)$} \\
\cline { 1 - 2 } Strain & Strain rate $\left(\mathbf{s}^{-1}\right)$ & & 950 \\
0.6 & 0.1 & 850 & 950 \\
0.6 & 10 & 850 & 950 \\
\hline
\end{tabular}

3. Results

\section{$3.1 \alpha+\beta$ alloys}

Results from Thermo-Calc were used only as guidelines for the compositions as the database used did not have all the reported phases in the alloys. The $\mathrm{b}$ stabiliser amounts added ( $\mathrm{Ta}, \mathrm{Zr}$ and $\mathrm{Nb}$ ) were varied until the phase proportion mimicked those of Figure 1a. The amount of $\mathrm{Ru}$ and $\mathrm{Cu}$ that was added was based on Jin et al. (2015) and Schutz (1996). Figures 1 and 2 show the phase proportion diagrams for the as-received alloys and the experimental 

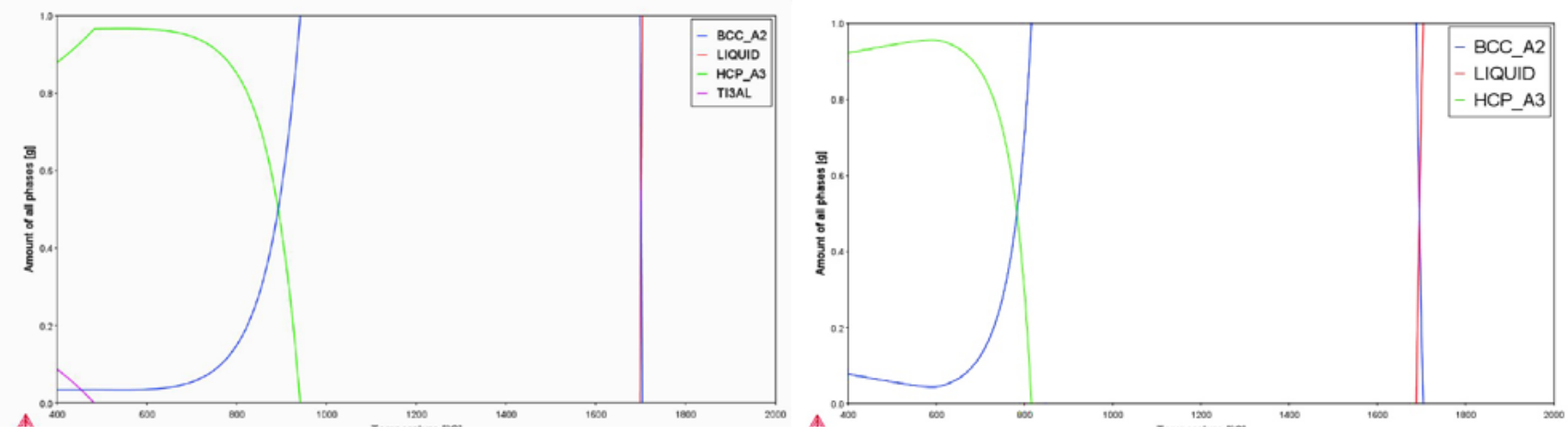

Figure 1. Phase proportion diagrams for: (a) Ti-6Al-4V (wt\%) and (b) Ti-10.1 Ta-1.7Nb-1.6Zr (wt\%).
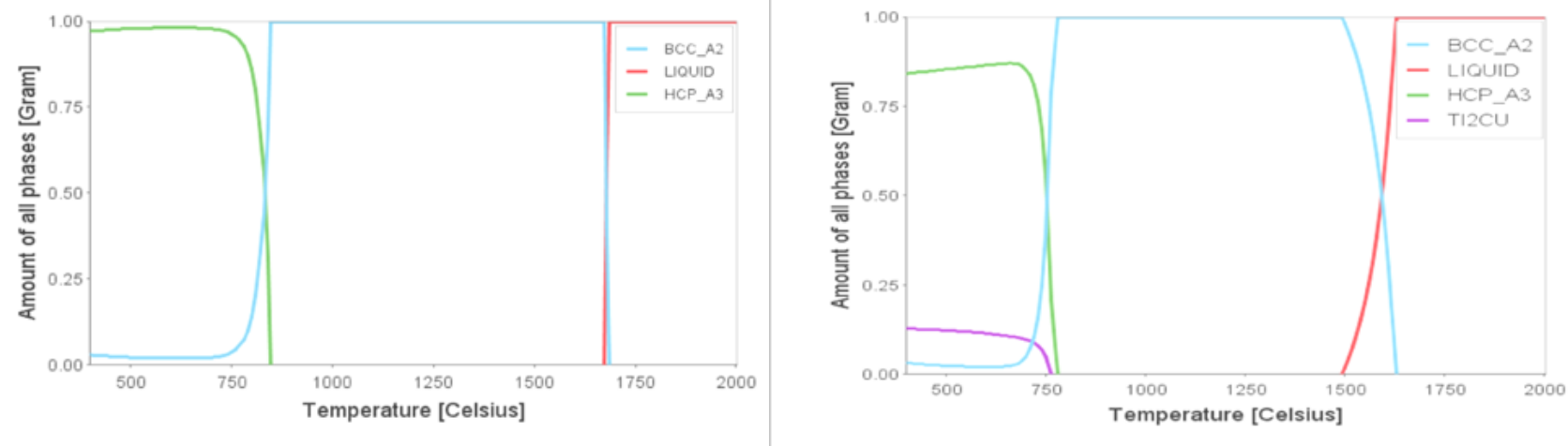

Figure 2: Phase proportion diagrams for: (a) Ti-6Ta-1.5Zr-0.2Ru (wt\%) and (b) Ti-6 Ta-1.5Zr-0.2Ru-5Cu (wt\%)

alloys. Figures $1 \mathrm{a}$ and $1 \mathrm{~b}$ show the phase proportions for Ti-6Al$4 \mathrm{~V}$ are $0.88 \alpha \mathrm{Ti}, 0.03 \beta \mathrm{Ti}$ and $0.09 \mathrm{Ti}_{3} \mathrm{Cu}$, and for TTNZ are 0.92 $\alpha \mathrm{Ti}$ and $0.08 \beta \mathrm{Ti}$ at $400{ }^{\circ} \mathrm{C}$ (at lower temperatures the results are less reliable). From Figure $2 \mathrm{a}$ the phase proportions were $0.97 \alpha \mathrm{Ti}$ and $0.03 \beta \mathrm{Ti}$ for Ti-6Ta-1.5Zr-0.2Ru and Ti-6Ta-1.5Zr-0.2Ru-5Cu had $0.84 \alpha \mathrm{Ti}, 0.03 \beta \mathrm{Ti}$ and $0.13 \mathrm{Ti}_{2} \mathrm{Cu}$ at $400{ }^{\circ} \mathrm{C}$ as shown in Figure $2 \mathrm{~b}$. The phase proportions were quite similar, and when $\mathrm{Cu}$ was added the $\mathrm{Ti}_{2} \mathrm{Cu}$ phase formed (Figure $2 \mathrm{~b}$ ).

Figure 3 shows the optical micrographs of the as-cast Ti- $8 \mathrm{Nb}-4 \mathrm{Zr}$ $x \mathrm{Cu}(x=0,5 \mathrm{wt} \%)$ alloys. The bimodal microstructure of Alloy 1 (Figure 3a) consisted of clusters of $\alpha$-laths within the transformed $\beta$ matrix. The black precipitates were thought to be the $\mathrm{Ti}_{2} \mathrm{Cu}$ phase (Figure $3 \mathrm{~b}$ ), which formed when $5 \mathrm{wt} \% \mathrm{Cu}$ was added. The EDX results of the Ti- $8 \mathrm{Nb}-4 \mathrm{Zr}-x \mathrm{Cu}(x=0,5 \mathrm{wt} \%)$ alloys indicated a higher $\mathrm{Cu}$ content in the light contrast $\beta$ Ti phase compared to the dark contrast $\alpha \mathrm{Ti}$ phase. The EDX analysis showed that the black precipitates (Figures $3 \mathrm{~b}$ ) were $\mathrm{Ti}_{2} \mathrm{Cu}$. The microstructures of Ti$8 \mathrm{Nb}-4 \mathrm{Zr}-x \mathrm{Cu}(x=0.5 \mathrm{wt} \%)$ showed similar $\alpha \mathrm{Ti}, \beta \mathrm{Ti}$ and $\mathrm{Ti}_{2} \mathrm{Cu}$ morphologies. The EDX analyses indicated higher $\mathrm{Cu}$ content in $\beta$ Ti phases than $\alpha \mathrm{Ti}$ in $\mathrm{Ti}-8 \mathrm{Nb}-4 \mathrm{Zr}-5 \mathrm{Cu}$. The solid solubility of $\mathrm{Cu}$ in $\beta$ Ti was $4.5 \pm 0.4 \mathrm{wt} \%$ for Ti- $8 \mathrm{Nb}-4 \mathrm{Zr}-5 \mathrm{Cu}$.

The SEM images are shown in Figures 4 and 5. Figures $4 a$ and $5 \mathrm{a}$ show the Ti-6Ta-1.5Zr and Ti-6Ta-1.5Zr-0.2Ru alloy microstructures, and Figures $4 \mathrm{~b}$ and $5 \mathrm{~b}$ shows the same alloys with $\mathrm{Cu}$ additions. The microstructures comprised mostly $\alpha \mathrm{Ti}$ layers. The alloys in Figures 4 and 5 all had $\alpha \mathrm{Ti}$ laths which precipitated at the prior $\beta \mathrm{Ti}$ grain boundaries. The $\mathrm{Cu}$-containing alloys (Figures $4 \mathrm{~b}$ and $5 \mathrm{~b}$ ) had less plate-like $\alpha \mathrm{Ti}$ phase and acicular $\alpha \mathrm{Ti}$.

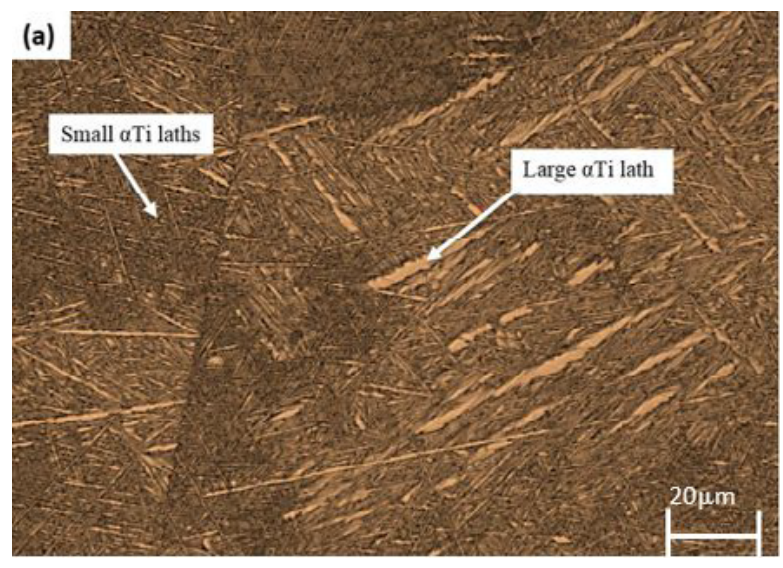

(b)

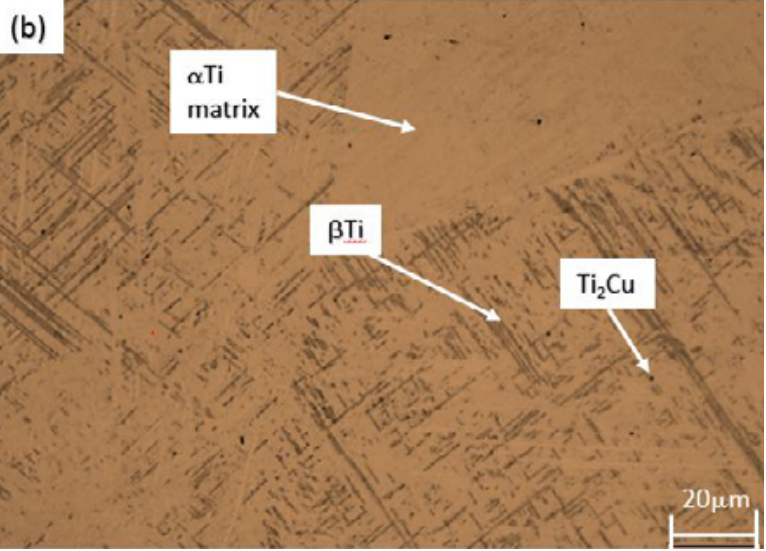

Figure 3: Optical micrographs of as-cast: (a) Ti-8Nb-4Zr showing clusters of $\alpha \mathrm{Ti}$ laths within prior $\beta \mathrm{Ti}$ grains and (b) Ti-8Nb-4Zr-5Cu (wt\%) showing $\beta \mathrm{Ti}, \alpha \mathrm{Ti}$ and $\mathrm{Ti}_{2} \mathrm{Cu}$ phases 

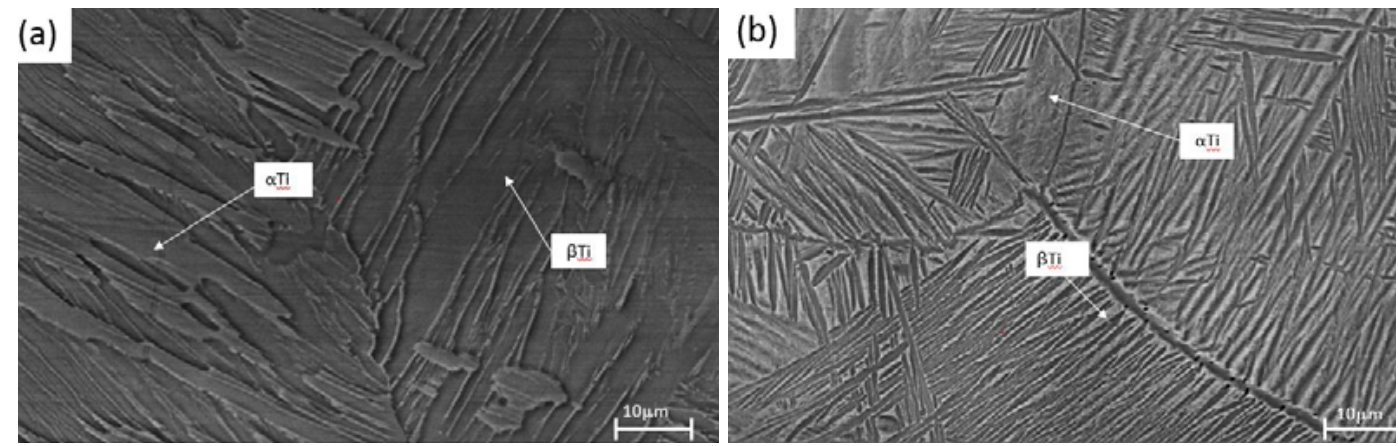

Figure 4: SEM-BSE images of as-cast: (a) Ti-6 Ta-1.5Zr (wt\%) and (b) Ti-6 Ta-1.5Zr-5Cu showing thick and thin (aTi) lamellae, growing from prior $\beta$ Ti grain boundaries
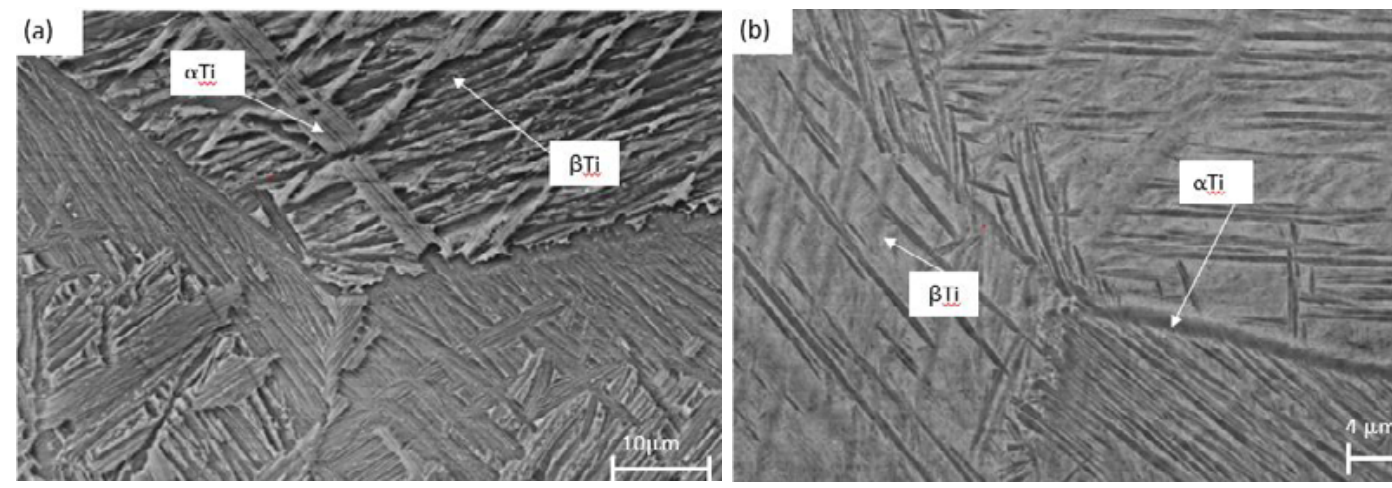

Figure 5: SEM-BSE images of as-cast: (a) Ti-6 Ta-1.5Zr-0.2Ru (wt $\%$ ) showing light contrast plate-like $\alpha \mathrm{Ti}$, and (b) Ti-6 Ta-1.5Zr-0.2Ru$5 \mathrm{Cu}$ showing parallel $\alpha \mathrm{Ti}$ laths growing from prior $\beta \mathrm{Ti}$ grain boundaries

The $\alpha$ Ti lamellae growing from the $\beta$ Ti grain boundaries into the matrix were present mostly in the alloys without $\mathrm{Cu}$ (Figures $4 \mathrm{a}$ and $5 \mathrm{a}$ ). With $\mathrm{Cu}$ additions the microstructures (Figures $4 \mathrm{~b}$ and $5 \mathrm{~b}$ ) exhibited needle-like and parallel $\alpha$ Ti plates, grown from the prior $\beta \mathrm{Ti}$ and into the matrix. Higher magnification had to be used to see the $\alpha \mathrm{Ti}$ plates in Ti-6Ta-1.5Zr-0.2Ru-5Cu (Alloy 3 ) compared to other alloys. The EDX analyses showed that the alloys without $\mathrm{Cu}$ had coarser $\alpha \mathrm{Ti}$ lamellae with more Ta, whereas the alloys with $\mathrm{Cu}$ had parallel $\alpha \mathrm{Ti}$ plates with more $\mathrm{Ta}$ and $\mathrm{Cu}$ than the nominal composition.

Figure 6 shows Alloy 4 (Ti-2Ta-8Mo-8Sn) with and without $\mathrm{Cu}$. The microstructure was apparently single-phase cored dendritic, and any second phase was in a small proportion, and could not be analysed accurately by EDX.

\subsection{Thermo-mechanical testing}

Hot deformation behaviour of the as-received Ti-6Al-4V reference material and $\mathrm{Ti}-10.1 \mathrm{Ta}-1.7 \mathrm{Nb}-1.6 \mathrm{Zr}$ alloys was evaluated and Figure 7 shows the stress-strain curves obtained from uniaxial compression testing. The microstructures as a function of deformation temperature and strain rates are shown in Figures 8-11. The strain rates for Ti-6Al-4V were higher at both temperatures compared to Ti-10.1Ta-1.7Nb-1.6Zr. For $10 \mathrm{~s}^{-1}$ strain rate the Ti$6 \mathrm{Al}-4 \mathrm{~V}$ at $950{ }^{\circ} \mathrm{C}$ was higher than $0.1 \mathrm{~s}^{-1}$ strain rate.
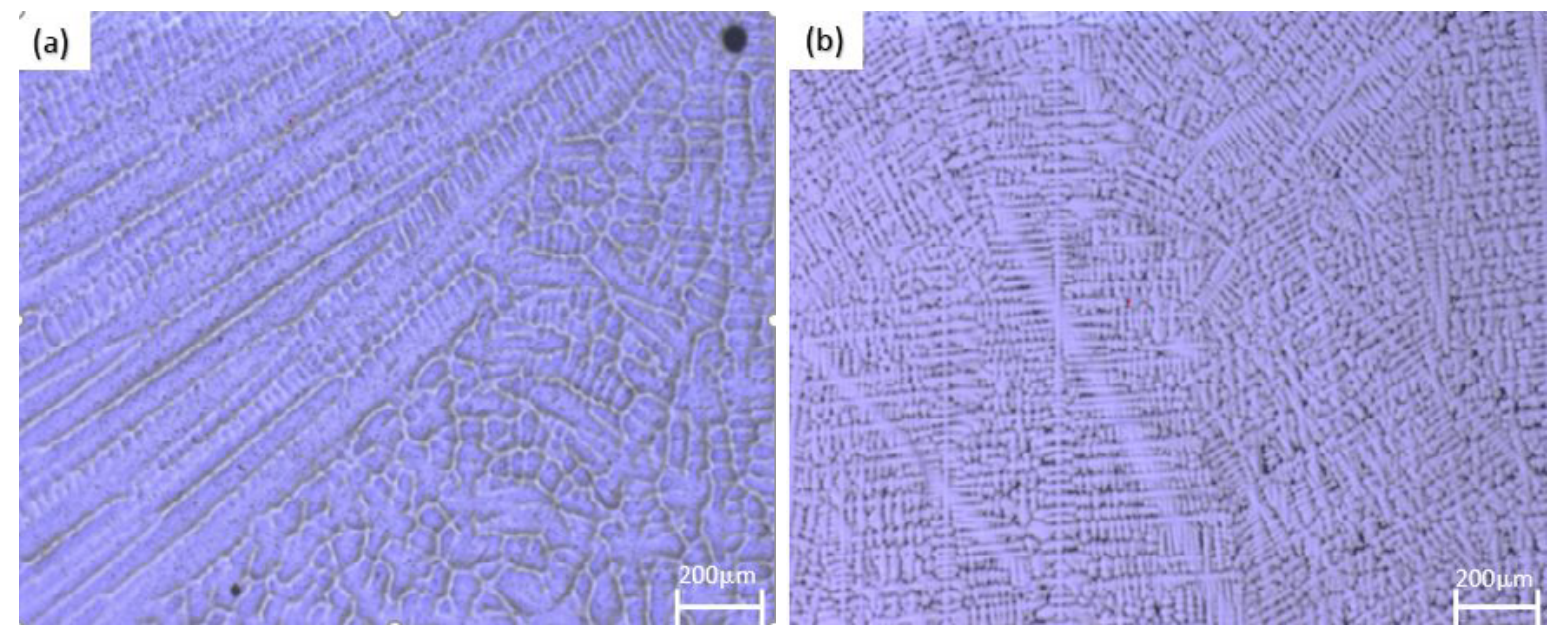

Figure 6: Optical micrographs of as-cast: (a) Ti-2Ta-8Mo-8Sn and (b) Ti-2Ta-8Mo-8Sn-5Cu (wt\%) showing mainly a cored dendritic structure, with small proportions $\left(\mathrm{Ti}_{2} \mathrm{Cu}\right)$ 
(a) $\varepsilon=0.1 \mathrm{~s}^{-1}$

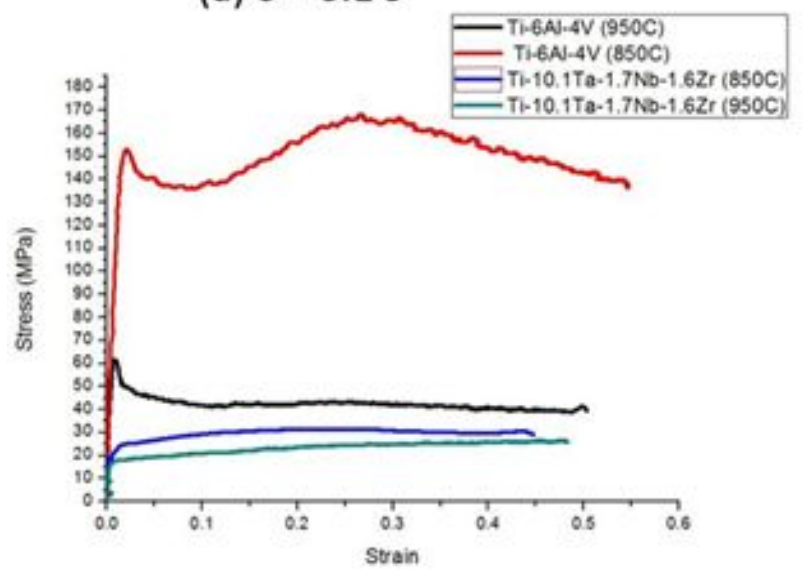

(b) $\varepsilon=10 \mathrm{~s}^{-1}$

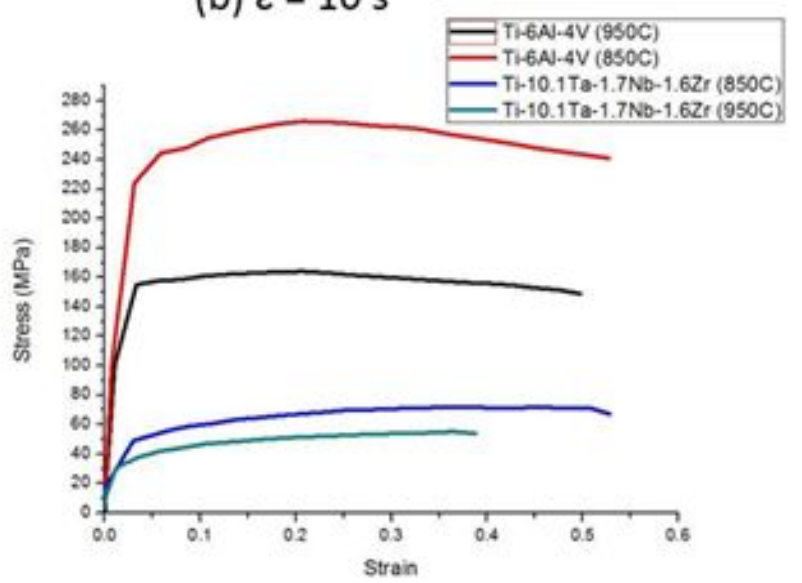

Figure 7: Stress-strain curves of the as-received Ti-6Al-4V and Ti-10.1 Ta-1.7Nb-1.6Zr (wt\%) alloys deformed at $850{ }^{\circ} \mathrm{C}$ and $950{ }^{\circ} \mathrm{C}$, at: (a) $0.1 \mathrm{~s}^{-1}$ and (b) $10 \mathrm{~s}^{-1}$ strain rates
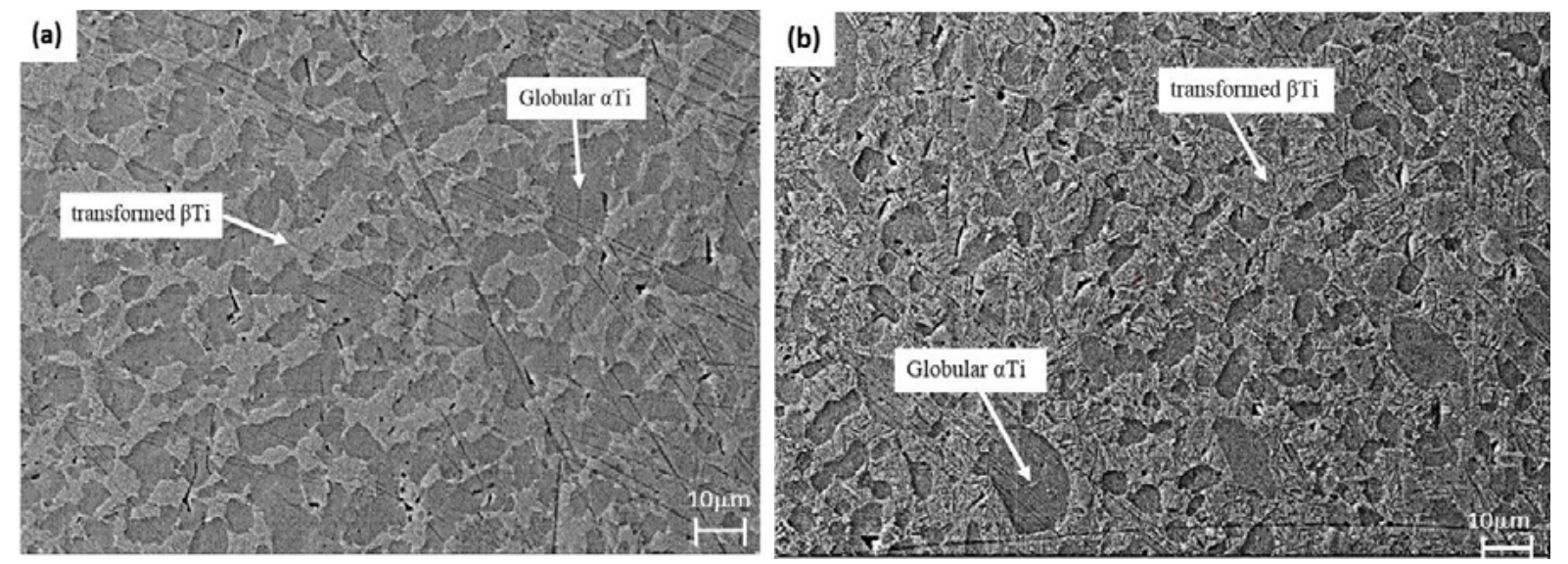

Figure 8: SEM-BSE images of Ti-6Al-4V deformed at $0.1 \mathrm{~s}^{-1}$ strain rate at: (a) $850{ }^{\circ} \mathrm{C}$ and (b) $950{ }^{\circ} \mathrm{C}$, showing $\beta$ Ti matrix (light contrast) and $\alpha$ Ti globules (dark contrast)

The SEM-BSE images (Figure 8) show $\alpha$ Ti globules within the transformed $\beta$ Ti matrix. At $950{ }^{\circ} \mathrm{C}$, the $\alpha$ Ti globules decreased in size. There were coarser $\alpha \mathrm{Ti}$ globules and grain coarsening at 850 ${ }^{\circ} \mathrm{C}$ (Figure 9a), and finer $\alpha \mathrm{Ti}$ globules at $950{ }^{\circ} \mathrm{C}$ (Figure 9b).

At $850{ }^{\circ} \mathrm{C}$, TTNZ comprised coarse $\alpha \mathrm{Ti}$ particles (Figure 10a), whereas at $950{ }^{\circ} \mathrm{C}$ there were fine $\alpha \mathrm{Ti}$ particles (Figure $10 \mathrm{~b}$ ). Figure 11 shows microstructures of globular $\alpha \mathrm{Ti}$ grains, and the $\beta \mathrm{Ti}$ matrix. The $\alpha \mathrm{Ti}$ globules appeared to be coarser at $950{ }^{\circ} \mathrm{C}$ (Figure 11b), than at $850^{\circ} \mathrm{C}$ (Figure 11a).

\section{Discussion}

\section{$4.1 \alpha+\beta$ alloys}

As the phase proportions for Ti-6Al-4V (Figure 1) and Ti-6Ta$1.5 \mathrm{Zr}-0.2 \mathrm{Ru}$ (Figure 2a) were similar, it is expected that Ti-6 Ta$1.5 \mathrm{Zr}-0.2 \mathrm{Ru}$ could replace Ti-6Al-4V and have similar properties.
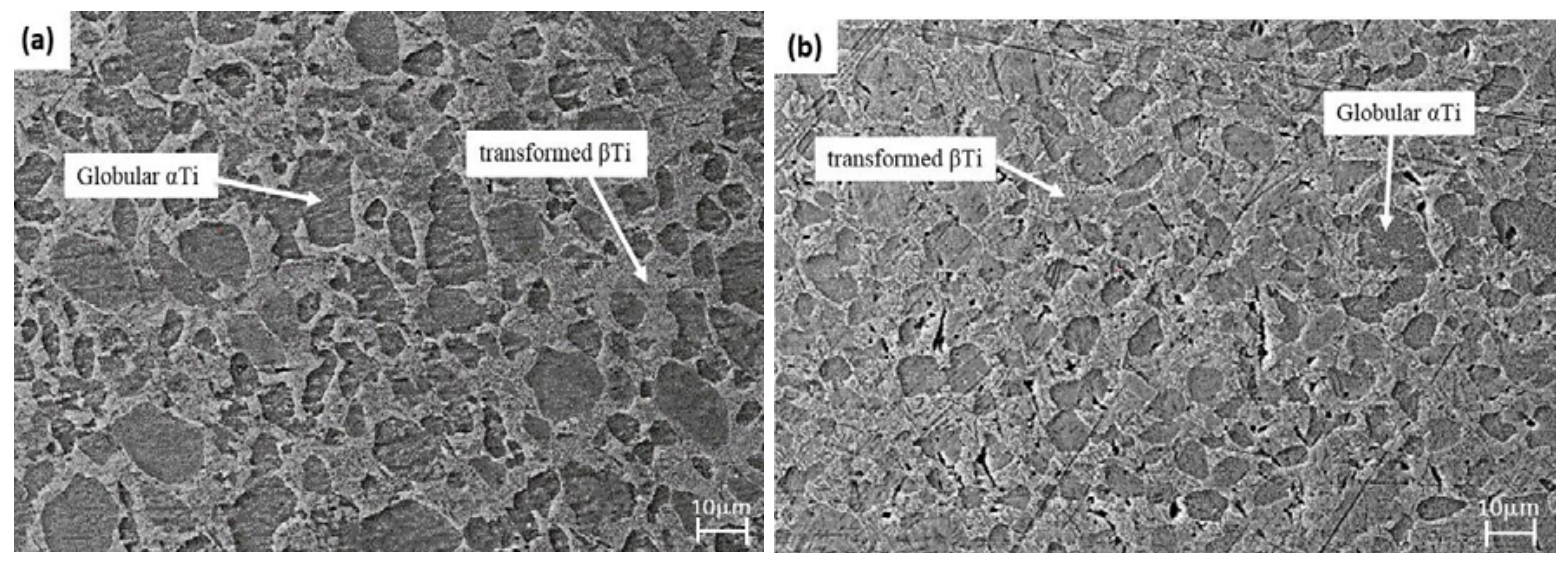

Figure 9: SEM-BSE images of Ti-6Al-4V (wt\%) deformed at $10 \mathrm{~s}^{-1}$ strain rate at: (a) $850{ }^{\circ} \mathrm{C}$ and (b) $950{ }^{\circ} \mathrm{C}$, showing $\beta$ Ti-matrix (light contrast) and $\alpha \mathrm{Ti}$ globules (dark contrast) 

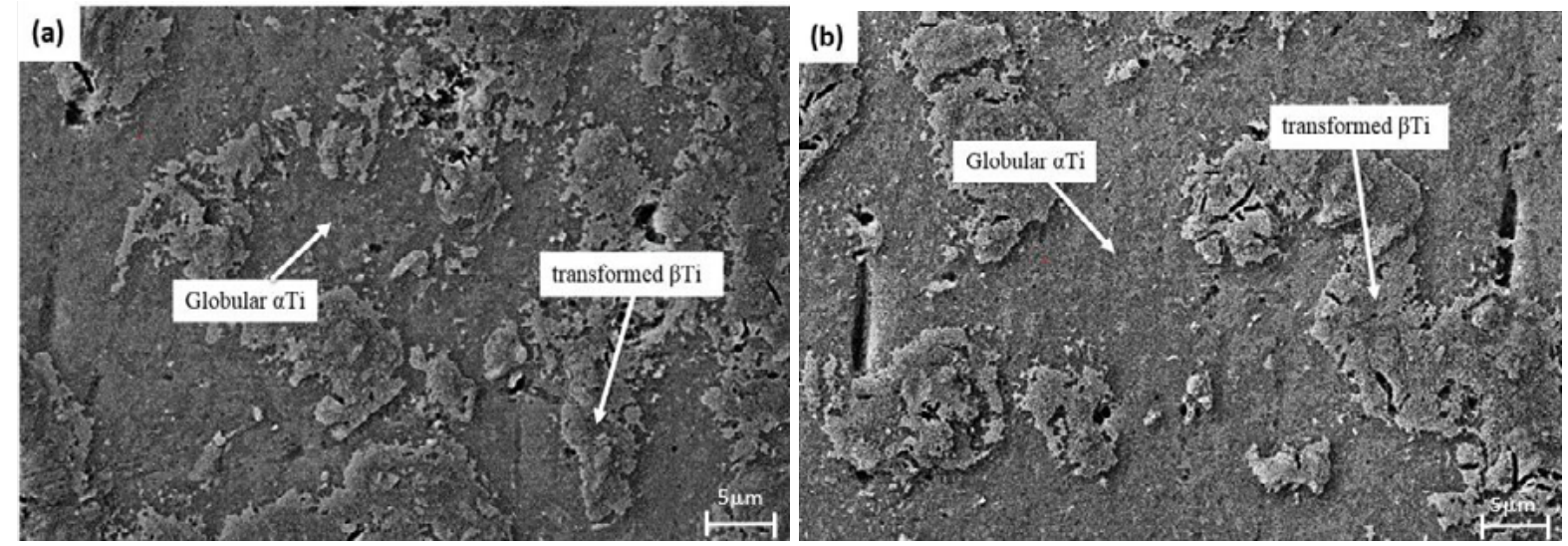

Figure 10: SEM-BSE images of Ti-10.1 Ta-1.7Nb-1.6Zr (wt\%) deformed at $0.1 \mathrm{~s}^{-1}$ strain rate at: (a) $850{ }^{\circ} \mathrm{C}$ and (b) $950{ }^{\circ} \mathrm{C}$, showing $\alpha \mathrm{Ti}$ particles in $\beta$ Ti matrix
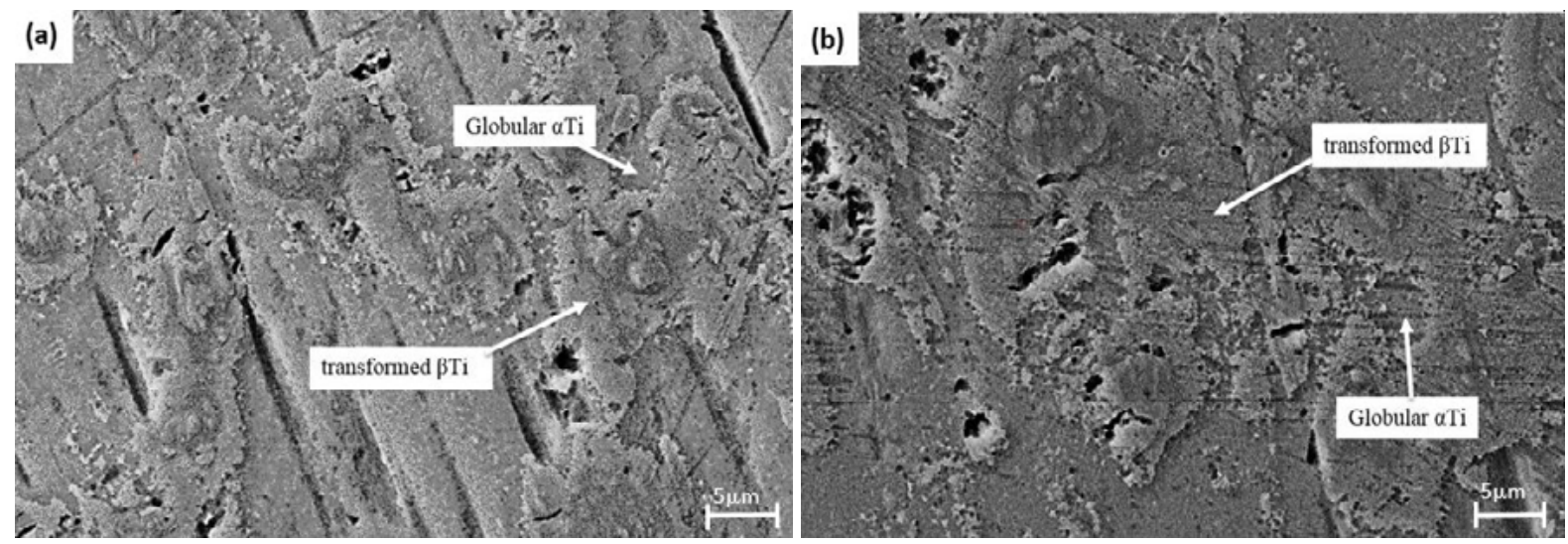

Figure 11: SEM-BSE images of Ti-10.1Ta-1.7Nb-1.6Zr (wt\%) deformed at $10 \mathrm{~s}^{-1}$ strain rate at: (a) $850{ }^{\circ} \mathrm{C}$ and (b) $950{ }^{\circ} \mathrm{C}$, showing $\alpha \mathrm{Ti}$ particles and $\beta$ Ti matrix

The phase proportion diagram in Figure $2 b$ shows that the $\alpha \mathrm{Ti}$ phase proportions decreased slightly and $\mathrm{Ti}_{2} \mathrm{Cu}$ formed when $\mathrm{Cu}$ was added to the alloy. The $\beta$ Ti phase proportion was not affected by the addition of $\mathrm{Cu}$.

Alloys 1-3 (Table 1) had similar morphologies, although Alloy 4 had a dendritic microstructure. Due to Alloy 4 not being clearly two-phase (there could have been a small amount of a second phase, but insufficient for the microstructure targeted), no further analysis was done on that alloy. Possibly, the alloy solidified as apparently single-phase because of the high cooling rate from arc-melting, which was not at equilibrium, whereas Thermo-Calc shows equilibrium phases and compositions. However, this shows that Alloy 4 was more cooling-rate dependent than the other alloys. Alloys 1-3 with $\mathrm{Cu}$ additions formed the $\mathrm{Ti}_{2} \mathrm{Cu}$ phase, which would improve the antibacterial properties of the alloys (Jin et al, 2005) and make them suitable candidates to replace the existing Ti alloys.

\subsection{Thermo-mechanical testing}

The thermo-mechanical results for Ti-10.1 Ta-1.7Nb-1.6Zr showed that ductility improved at higher temperature $\left(950^{\circ} \mathrm{C}\right)$ and lower strain rate $\left(0.1 \mathrm{~s}^{-1}\right)$, and at lower temperature $\left(850^{\circ} \mathrm{C}\right)$ and higher strain rate $\left(10 \mathrm{~s}^{-1}\right)$. The ductility of Ti-6Al-4V improved at lower deformation temperature, consistent with Prozesky et al. (2017) and Dos Santos et al. (2017). An increased strain rate $\left(10 \mathrm{~s}^{-1}\right)$ led to increased flow stress, compared to $0.1 \mathrm{~s}^{-1}$, and increasing the temperature $\left(950{ }^{\circ} \mathrm{C}\right)$ gave reduced flow stress for both Ti-6Al$4 \mathrm{~V}$ and Ti-10.1Ta-1.7Nb-1.6Zr alloys. The Ti-6Al-4V alloy had higher flow stress $\left(170 \mathrm{MPa}\right.$ at $0.1 \mathrm{~s}^{-1}$ and $270 \mathrm{MPa}$ at $\left.10 \mathrm{~s}^{-1}\right)$ than Ti-10.1 Ta-1.7Nb-1.6Zr (35 MPa $0.1 \mathrm{~s}^{-1}$ and $75 \mathrm{MPa}$ at $\left.10 \mathrm{~s}^{-1}\right)$ at 850 ${ }^{\circ} \mathrm{C}$. The Ti-6Al-4V and Ti-10.1Ta-1.7Nb-1.6Zr alloys had steadystate flow stress at $950^{\circ} \mathrm{C}$, and continuous flow softening at $850^{\circ} \mathrm{C}$ for both $0.1 \mathrm{~s}^{-1}$ and $10 \mathrm{~s}^{-1}$ strain rates.

The Ti-6Al-4V alloy deformed at $850{ }^{\circ} \mathrm{C}$ and $0.1 \mathrm{~s}^{-1}$ had elongated $\alpha$ Ti laths (Figure 6a), which grew into globular $\alpha$ grains at 950 ${ }^{\circ} \mathrm{C}$ and $10 \mathrm{~s}^{-1}$ (Figure 7b). This suggested that globularisation of $\alpha$ Ti occurred from the higher strain rate and increased deformation temperature. Thus, a higher deformation temperature and strain rate gave a finer Ti-6Al-4V microstructure. The deformed Ti-6Al$4 \mathrm{~V}$ microstructures were different from the initial microstructure, which were fully $\alpha \mathrm{Ti}$ lamellar microstructures.

The microstructures of the TTNZ alloy before and after deformation (Figures 8 and 9) were similar, with globular $\alpha \mathrm{Ti}$ grains. At $850{ }^{\circ} \mathrm{C}$ and $10 \mathrm{~s}^{-1}$ (Figure 9a), and at $950{ }^{\circ} \mathrm{C}$ and $0.1 \mathrm{~s}^{-1}$ (Figure 8b), there were finer $\alpha \mathrm{Ti}$ globules, similar to the initial microstructure. The coarser $\alpha \mathrm{Ti}$ globules at $850{ }^{\circ} \mathrm{C}$ and $0.1 \mathrm{~s}^{-1}$ (Figure 8a) and $950{ }^{\circ} \mathrm{C}$ and $10 \mathrm{~s}^{-1}$ (Figure $9 \mathrm{~b}$ ) suggested that a combination of lower temperature and higher strain rate, and/or a higher temperature and lower strain rate, would produce finer microstructures. 


\section{Conclusions}

The Ti-8Nb-4Zr alloys studied had bimodal microstructures comprising $\alpha \mathrm{Ti}$ laths in a transformed $\beta$ matrix. Alloys without $\mathrm{Cu}$ (Alloys 2 and 3 ) had coarser $\alpha$ Ti lamellae with more Ta, whereas the alloys with $\mathrm{Cu}$ had parallel $\alpha \mathrm{Ti}$ plates with higher $\mathrm{Ta}$ and $\mathrm{Cu}$ contents. All the alloys with $\mathrm{Cu}$ formed sufficient $\mathrm{Ti}_{2} \mathrm{Cu}$, except for Alloy 4 which had only small amounts. Alloy 4 was the only unsuccessful alloy, as it did not have a sufficientyly high proportion of the second phase as the other alloys.

Higher flow stresses were obtained at higher strain rates $\left(10 \mathrm{~s}^{-1}\right)$ and lower temperature $\left(850^{\circ} \mathrm{C}\right)$. At $850^{\circ} \mathrm{C}$, the Ti-6Al-4V alloy had higher flow stresses (170 MPa at $0.1 \mathrm{~s}^{-1}$ and $270 \mathrm{MPa}$ at $\left.10 \mathrm{~s}^{-1}\right)$ than Ti-10.1 Ta-1.7Nb-1.6Zr (35 MPa $0.1 \mathrm{~s}^{-1}$ and $75 \mathrm{MPa}$ at $\left.10 \mathrm{~s}^{-1}\right)$. The Ti-6Al-4V and Ti-10.1 Ta-1.7Nb-1.6Zr alloys had steady-state flow stresses at $950{ }^{\circ} \mathrm{C}$, and continuous flow softening at $850^{\circ} \mathrm{C}$ for both $0.1 \mathrm{~s}^{-1}$ and $10 \mathrm{~s}^{-1}$ strain rates.

\section{Acknowledgements}

This work was supported by the National Research Foundation [Grant numbers 41292, STNT170905261815].

\section{Contribution of each author}

K Dyal Ukabhai undertook calculations, experiments and wrote the paper; K T Nape, L Spotose and M Mavundla undertook calculations and experiments; I A Mwamba gave advice on some aspects and was the Mintek co-supervisor; M O Bodunrin gave advice on calculations and thermomechanical simulations; $\mathrm{L} \mathrm{H}$ Chown co-supervised all the students, hosted the postdoctoral fellow and helped with the interpretation; and L A Cornish conceived the overall project, co-supervised the students, helped with interpretation and checked the writing of the paper.

\section{References}

1. Bodunrin M.O. 2018. Hot deformation and corrosion behaviour of low-cost $\alpha+\beta$ titanium alloys with aluminium, vanadium and iron additions, School of Chemical and Metallurgical Engineering, University of the Witwatersrand, Johannesburg. PhD Thesis, 1-293.

2. Bundy K J, Marek M and Hochman R F. 1983. In vivo and in vitro studies of the stress-corrosion cracking behaviour of surgical implant alloys. Journal of Biomedical Materials Research 17, 467-87.

3. Burnstein A, Reilly D and Martens M. 1976. Aging of bone tissue: mechanical properties. Journal of Bone and Joint Surgery 58 (1), $82-86$.

4. Calin M, Zhang L C and Eckert J. 2007. Tailoring of microstructure and mechanical properties of a Ti-based bulk metallic glass-forming alloy. Scripta Materialia 57 (12), 1101-1104.

5. Choubey A, Balasubramaniam R and Basu B. 2004. Effect of replacement of $\mathrm{V}$ by $\mathrm{Nb}$ and $\mathrm{Fe}$ on the electrochemical and corrosion behaviour of Ti-6Al-4V in simulated physiological environment. Journal of Alloys and Compounds 381 (1), 288-294.

6. Dos Santos M W B. 2017. Investigation of the mechanical behaviour and microstructural evolution of titanium alloys under superplastic and hot forming conditions. Ecole des Mines d'Albi-Carmaux Polytechnic School of Engineering of the University of Sao Paulo (EPUSP).
7. Eisenbarth E, Velten D, Müller M, Thull R and Breme J. 2004 Biocompatibility of $\beta$-stabilizing elements of titanium alloys. Biomaterials 25, 5705-13

8. Geetha M, Singh A K, Asokamani R and Gogia A K. 2009. Ti based biomaterials, the ultimate choice for orthopaedic implants - A review. Progress in Materials Science 54 (3), 397-425.

9. Jha B K and Kumar V. 2010. Role of thermo-mechanical simulation in the development of special steel products. Proceedings of National Conference and $2^{\text {nd }}$ Gleeble User Workshop RDCIS Ranchi 1-10.

10. Jin L G X, Liu E, Yu F, Shu X and Wang H. 2015. Microstructure, corrosion and tribological and antibacterial properties of $\mathrm{Ti}-\mathrm{Cu}$ coated stainless steel. Journal of the Mechanical Behaviour of Biomedical Materials 50, 23-32.

11. Khan W, Marew T and Kumar N. 2006 Immobilization of drugs and biomolecules on in situ copolymerized active ester polypyrrole coatings for biomedical applications. Biomedical Materials 1 (4). 235-241.

12. Kuroda D, Niinomi M, Morinaga M, Kato Y and Yashiro T. 1998. Design and mechanical properties of new $\beta$ type titanium alloys for implant materials, A Structure and Material Properties, Microstructural Process. Materials Science and Engineering A 243, 244-249.

13. Li Y, Yang C, Zhao H, Qu S, Li X and Li Y. 2014. New developments of Ti-based alloys for biomedical applications. Journal of Materials 7 (3), $1709-1800$.

14. Lindahl O and Lindgren A G H. 1967. Cortical bone in man: II. Variation in tensile strength with age and sex. Acta Orthopaedica Scandinavica 38, 141-147.

15. Meng Q, Guo S, Liu Q, Hu L and Zhao X. 2014. A ß-type TiNbZr alloy with low modulus and high strength for biomedical applications. Progress in Natural Science: Materials International 24, 157-162.

16. Mitragotri S and Lahann J. 2009. Physical approaches to biomaterial design. Nature Materials 8, 15-23.

17. Navarro M, Michiardi A, Castaño O and Planell J A. 2008. Biomaterials in orthopaedics. Journal of the Royal Society Interface 5 (27), $1137-1158$.

18. Okazaki Y and Gotoh E. 2005. Comparison of metal release from various metallic biomaterials in vitro. Biomaterials 26 (1), 11-21.

19. Persson G R and Renvert S. 2014. Cluster of bacteria associated with peri-implantitis. Clinical Implant Dentistry and Related Research 16 (6), 783-793.

20. Prozesky D J, Bodunrin M O and Chown L H. 2017. Hot-deformation behaviour of $\alpha+\beta$ Ti-Al-V-Fe experimental alloys. AIP Conference Proceedings. 1896 1160019-1-6 https://doi.org/10.1063/1.5008194.

21. Schutz R W. 1996. Ruthenium enhanced titanium alloys. Platinum Metals Review 40 (2), 54-61.

22. Shaikh A A, Kashyap B P and Chauthai A. 2015. Identification of Favorable Hot Working Condition for Ti-6Al-4V Alloy. National Conference on Thermo-mechanical processing of Steels \& 5th Gleeble User Workshop, India, 78-91.

23. Sidambe A T. 2014. Biocompatibility of advanced manufactured titanium implants - a review. Materials 7 (12), 8168-8188.

24. Stenlund P, Omar O, Brohede U, Norgren S, Norlindh B, Johansson A, Lausmaa J, Thomsen P and Palmquist A. 2015. Bone reponse to a novel Ti-Ta-Nb-Zr alloy. Acta Biomaterialia 20, 165-175.

25. Nang S, Banerjee R, Stechschulte J and Fraser H L. 2005. Comparison of microstructural evolution in Ti-Mo-Zr-Fe and Ti-15Mo biocompatible alloys. Journal of Materials Science: Materials in Medicine 16 (7), 679-685.

26. Tamilselvi S, Raman V and Rajendran N. 2006. Corrosion behaviour of Ti-6Al-7Nb and Ti-6Al-4V ELI alloys in the simulated body fluid solution by electrochemical impedance spectroscopy. Electrochimica Acta 52 (3), 839-846.

27. Vanderhasten M. 2008. Ti-6Al-4V: Deformation map and modelisation of tensile behavior.

28. Katholieke Universiteit Leuven. Doctoral Thesis, 1-150.

29. Zhang L C, Kim K B, Yu P, Zhang W Y, Kunz U and Eckert J. 2007. Amorphization in mechanically alloyed $(\mathrm{Ti}, \mathrm{Zr}, \mathrm{Nb})-(\mathrm{Cu}, \mathrm{Ni})-\mathrm{Al}$ equiatomic alloys. Journal of Alloys and Compounds 428, 157-163.

30. Zhang L C, Klemm D, Eckert J, Hao Y L and Sercombe T B. 2011. Manufacture by selective laser melting and mechanical behaviour of a biomedical Ti-24Nb-4Zr-8Sn alloy. Scripta Materialia 65 (1), 21-24. 